\title{
RAD52 Gene
}

National Cancer Institute

\section{Source}

National Cancer Institute. RAD52 Gene. NCI Thesaurus. Code C106263.

This gene is involved in both double-strand break repair and homologous recombination. 